\title{
Students What Should Be Minded When Families With Disabled Children Are Planning A Summer Vacation?
}

\author{
Erkan GULGOSTEREN ${ }^{1}$, Pervin TOPTAŞ DEMIRC $\dot{I}^{2}$, Ali DEMIRCI ${ }^{1}$ \\ ${ }^{1}$ Mersin University, Physical Education and Sport Sciences, Mersin/Turkey \\ ${ }^{2}$ Mersin University Department of Tourism Animation, Mersin/Turkey \\ *Corresponding author: egulgosteren@mersin.edu.tr
}

\begin{abstract}
Introduction: Many people with disabled children living in Turkey are affected by psychological, sociological, economic and emotional disabilities due to their children's disabilities. In this respect, the well-planned free time periods outside of the training period give children with disabilities the freedom to move freely. In this research, it is aimed to investigate what matters to pay attention to when planning vacation for children with disabilities. A structured interview form with 34 items was prepared in order to plan summer vacation about families with disabled children in the research. The field survey was conducted and interview questions and the content of the survey were generated. In Mersin province, private rehabilitation was discussed individually with 136 volunteer mothers in the training and application centers for the disabled. With the prepared questions, it was tried to investigate the expectations of the expectant mothers who have children with disabilities while planning a summer holiday. According to the interview data, it was observed that the mothers were more difficult to construct the holiday content, but showed more protective behavior tendencies. According to the information provided, it is stated that the children who take part in the mothers' tours will take care of the age groups, the girls and boys separately and the importance of accompanying specialists, educators, health personnel and caring individuals. The different types of obstacles and accompanying diseases of each child are the other issues that are emphasized. Other information reported by the family includes information about eating and sleeping habits, special behaviors, favorite toys, drugs used, fears, allergic conditions, underbelly, and being aggressive. As a result; It should be emphasized that When choosing a summer vacation program, it is important for families to consider the child's age, interests and personality. It should also be considered how the holiday activities will support children's learning throughout the year.
\end{abstract}

\section{Keywords}

Disabled Children, Families, Holiday Planning, Independent Living, Self-Confidence

\section{INTRODUCTION}

The European population ages from day to day. There are approximately 37 million disabled and 120 million disabled elderly individuals living in Europe (EU (2004). It is estimated that 74\% (116 million) of this community, consisting of a total of 157 million individuals, are travelable individuals (Metin, 2013). It is foreseen that by 2050 Europe will be over 65 years old and over three times more than in 2003 and will be five times as high as the population aged 80 years (EU2013). There are more than 8.5 million people with disabilities in our country (Eryılmaz, 2010). It is important to continue uninterrupted rehabilitation and training with appropriate programs in all disability groups. Holiday programs to be planned after training are necessary in this respect. The necessity of being a contemporary society and ensuring that every individual who lives in society as a fundamental human right has equal access to all services and facilities (Eryılmaz, 2010). In a disability life, they face different challenges and generally have limitations in participating in some activities. Whether disabled or not, traveling is a situation that everyone desires (Yau, et al., 2004) and is a right according to Article 23 of the Constitution in our country (Resmi Gazete, 1982). Achieving full participation of people with disabilities in the life 
of society and raising their living standards is a requirement of contemporary society (Okur, 2001). From this point of view, an increase in the participation of children with disabilities in holiday organizations is observed in our country. Many local governments produce social projects for disadvantaged groups or make free use of children with disabilities by making their own budgets and summer holiday planning (Interview, 2016).

The well-planned free time periods outside the train ing period give children with disabilities the freedom to move. Having fun with the game, education is an important time for children with disabilities. Child movement and play are most needed in the first stage of kindergarten and primary education. In this period, the child's tendencies should be considered and all activities should be considered within the context of gaming and gaming movements (Demirci, 2004). Played events can be tools for improving the child's learning ability. A child who develops positive attitudes and attitudes towards learning can participate more actively in learning interactions. This participation makes the receptors that influence the perception of the child more selective and motivates them to learn the relevant topic. This will make the child ready (Koca, 2012). The well-planned free time periods outside the training period give children with disabilities the freedom to move. It therefore opens the way for the disabled child to become an independent, selfsufficient

individual by giving them daily skills (Gur, 2001). Having fun with the game, education is an important time for children with disabilities (Şahin, 2001). Child movement and play are most needed in the first stage of kindergarten and primary education. In this period, the child's tendencies should be considered and all activities should be considered within the context of gaming and gaming movements (Demirci, 2004). Played events can be a tool for improving the child's learning ability (Ozer,

2010). A child who develops positive attitudes and attitudes towards learning can participate more actively in learning interactions. Thus, the basic motor skills (Demirci, 2013, Demirci, 2006), such as strength, speed and durability, which are the aim of motor development, are developed. This participation makes the receptors that influence the perception of the child more selective and motivates them to learn the relevant topic. This will make the child ready (Camliyar, 1987, Koca, 2012). It is known that play, physical education and sports activities which will take place in the summer holiday programs contribute to the survival of the disabled people with physical, mental, psychological and social structure in a way that is compatible and integrated with itself and society (Okur, 2001, Ozturk, 1998). Children with disabilities in gaming and sporting activities provide a good understanding, initiative, development of integration, and development of love, self-respect, and life (Hazar, 1997). Rehabilitation, freedom of movement and freedom to exercise live in programs designed to edited them (Okur, 2001). At the beginning of these programs are holiday programs. In the light of this information; it is aimed to investigate the points to be taken into consideration when planning vacations for children with disabilities.

\section{MATERIALS AND METHODS}

A meeting was held in order to learn about a holiday plan that the families with children with disabilities wanted to do in the research and a structured interview form with 34 items was prepared by evaluating the results of these meetings. The field survey was conducted and the content of the interview questions and the research was established (TR62-09- 02/04, 2009). For each item in the interview form that was created, the families were asked to grade between 0 and 100 points. In Mersin province, private rehabilitation centers and state-owned disability centers were individually interviewed with 136 mothers voluntarily at the training and application centers. "Informed Consent Form" was received from the participating mothers in accordance with Helsinki. In the prepared questions, it was tried to investigate the expectations of the mothers by planning the holidays by taking the information that the children can not make holiday alone.

\section{Statistical analyzes}

All statistical analyses were performed by SPSS version 18 Results of descriptive statistics in this study are presented as mean, standard deviation, and percentage rate. 


\section{RESULTS}

According to the table, the rate of the mothers who stated that the age groups of the children who will attend the holiday are close to each other is expressed as $81.6 \%$. It was observed that $76.9 \%$ of the mothmothers participated in the expression of the need to pay to the separate groups of girls and boys when planning vacations for disabled children. When planning vacations for disabled children, $95.6 \%$ emphasized the necessity of health personnel. The planning of holidays for children with disabilities should be done at least 3 times a year. $65.5 \%$ of mothers should be done at least 2 times a year, $72.1 \%$ of them should be done at least once a year and $46.4 \%$ of them are born. $91.8 \%$ of children said that games and sport activities should be included in planning holiday for disabled children, while $94.8 \%$ of the children said that they are more closely connected with their life after holiday and they are happier. I do not think my handicapped child will be happy after the holiday, the rate of the mother is $48.5 \%$. $33.9 \%$ of the mothers said that no institution would take risks by planning vacation with children with disabilities, $66.1 \%$ of mothers received this expression positively. Our child can not adapt to holiday conditions and the proportion of mothers who can not adapt can be $67.6 \% .39 .7 \%$ of the mothers who say that they will not be able to reach the holiday goal and $45.6 \%$ of the mothers who say that the siblings will be adversely affected when they are vacationing with disabled children. Other people at the holiday place are $61 \%$ of the mothers who think they are disturbed because of our children with disabilities, $87.5 \%$ of the mothers who are uncomfortable because of people are uncomfortable and $56 \%$ of the mothers who say that we can not relax with our disabled children (Table 1).

Table 1. Opinions of Mentally Handicapped Children about Vacation Planning for Family about

\begin{tabular}{|c|c|c|}
\hline Family expectations & $\mathbf{n}$ & $\%$ \\
\hline Age groups are close to each other & 111 & 81.6 \\
\hline Care must be taken to ensure that boys and girls are separated & 104 & 76.9 \\
\hline There must be health personnel & 129 & 95.6 \\
\hline Expert trainers in the field must be & 129 & 95.6 \\
\hline There should be maintenance staff & 131 & 96.3 \\
\hline My child's accompanying disease should be considered & 121 & 88.9 \\
\hline The habits of eating and obeying must be known & 88 & 65.4 \\
\hline $\begin{array}{l}\text { Special behaviors of children should be taken into account (fear of kidnapping, aggression,loving toys, } \\
\text { and things they like) }\end{array}$ & 125 & 91.8 \\
\hline Drugs used, allergic conditions should be listed ratio of diarrhea & 133 & 98.2 \\
\hline $\begin{array}{l}\text { It is important for our children that the swimming pools, parks, natural beauty, entertainment center in } \\
\text { the facility to be visited are accessible while vacation planning is done for children with disabilities }\end{array}$ & 101 & 74.3 \\
\hline Vacation planning for children with disabilities should be done at least three times a year & 88 & 65.5 \\
\hline Vacation planning for disabled children should be done at least twice a year & 98 & 72.1 \\
\hline Vacation planning for disabled children should be done at least once a year & 63 & 46.4 \\
\hline Games and sports activities should be included when planning holidays for disabled children & 125 & 91.8 \\
\hline My child gets tighter after death and gets happier & 129 & 94.8 \\
\hline My child can not holiday without me & 110 & 80.9 \\
\hline My disabled child needs my protection in every part of my life & 128 & 94.2 \\
\hline My disabled child can not be happy without me even if he makes a holiday on a regular basis & 92 & 67.6 \\
\hline I do not think my disabled child will be happy after the holidays & 66 & 48.5 \\
\hline No institution takes risks by planning holidays with children with disabilities & 46 & 33.9 \\
\hline It may be possible for a child to have a holiday with his teachers teaching throughout the year & 121 & 89 \\
\hline Regular holiday planning will help my child's quality of life & 128 & 94.1 \\
\hline $\begin{array}{l}\text { It would be better if all members of the family had a regular holiday on their own without being } \\
\text { dependent on any institution }\end{array}$ & 122 & 89.7 \\
\hline Due to economic conditions, we have not had the opportunity to holiday until now & 122 & 89.7 \\
\hline Our child can not adapt to holiday conditions and can not adapt & 92 & 67.6 \\
\hline The proportion of parents who will not be able to reach the purpose of our holiday & 54 & 39.7 \\
\hline Other brothers are negatively affected while vacationing with disabled children & 62 & 45.6 \\
\hline The spaciousness of the family will increase the quality of the holiday and $\mathrm{r}$ & 96 & 70.5 \\
\hline
\end{tabular}




\begin{tabular}{|l|c|c|}
\hline each party decreases the load during the holiday & & \\
\hline In the care of the handicapped child, when the family said that the whole burden was on them & 122 & 89.8 \\
\hline $\begin{array}{l}\text { The spaciousness of the family does not diminish the burden of the mother in the care of the child } \\
\text { during the holiday }\end{array}$ & 92 & 67.6 \\
\hline the father is as effective as the mother in the care and education of the child & 104 & 76.5 \\
\hline Other people at the resort are uncomfortable with us because of our disabled children & 83 & 61 \\
\hline People are uncomfortable affecting us & 119 & 87.5 \\
\hline We can not relax wherever we go with our disabled child & 76 & 56 \\
\hline
\end{tabular}

\section{DISCUSSION AND CONCLUSION}

Early diagnosis and training for children with disabilities is important for future independent life. InMay 1980 UNICEF adopted a policy of expanding existing work to prevent and rehabilitate disabilities in childhood (Karatepe, 1998). The essence of this new strategy, prepared by "Rehabilitation International" for UNICEF, encompasses all of the existing health, nutrition, education and social welfare programs for children and their families to live beter (Karatepe, 1998).

This program included the principles of "prevention of disabilities, early identification of physical, mental and emotional disorders, measures to be taken by society and the family, maximum treatment and rehabilitation" (Karatepe1998). Many of the people with disabled children who live in our country whe Adequate measures can not be taken, are affected by psychological, sociological, economical and emotional negative effects due to the obstacles of their children. First, they refused to have children with disabilities, had mixed emotions, felguilt, embarrassment, and resentment (Gur, 2001).

Families who find a way to rearrange their experience by accepting the current situation with expert support have integrated their lives into society by planning their lives according to the disabled child. In this respect, it is important that children with disabilities have to make use of education and rehabilitation services sufficiently to develop their independent lives. In the course of child rehabilitation activities, he is able to do a lot of exercises. Moving is the nature of human life (Demirci, 2013). Movement is life. Everything we do in our work and in our game covers movement (Yorukoğlu, 1981). It is important to plan the training and prepare the games in many forms of movement suitable for the development of the child. If developmental stages are well known, the origins of personality, the origins of positive and negative behaviors can be explained (Kephart, et al., 1973) and successful programs can be made in this direction. The movement patterns of the child's daily activities are collected in two major categories. These include: large muscle movements (using body) and small muscle movements (using objects) (Ozer, 2009). Organized games are especially valuable for developing large and small muscle groups. In this regard, educational games are good organizations that provide good behavior and habits that provide healthy development of the child's soul and body, playful joy and pleasure (EU, 2004).

Participation in well-programmed summer camps for children with disabilities allows rehabilitation and education to continue throughout the year if consideredin this framework. Children with disabilities who continue to be educated in the same environment throughout the year participate in different camps in different settings and enjoy more positive mental, spiritual, emotional, academic and motorsal developments and have more positive attitudes. The number of people with disabilities is increasing day by day in our country, the problems that people with disabilities are experiencing. Due to these problems in life, integration with society becomes difficult and individuals feel unhappy because solutions are not produced to problems. In this context, within the framework of the equal opportunity principle, it is necessary to make use of the same conditions as other individuals in the obstacles to the possibilities of social life (Gallahue et al., 2014). The most important condition for achieving full participation is availability (Gallahue et al., 2014, Eryılmaz, 2010). In this way, however, the quality of life of disabled people increases and it is possible to benefit as much as possible from all the opportunities offered by each individual, from opportunities, to planning. And in this way equal living standards are achieved. According to the interview data, it was observed that the mothers 
were more difficult to construct the holiday content and showed more protective behavior tendencies. According to theinformation provided, it is stated that the children who will participate in the mothers' tours pay attention to age groups, girls and boys separately and the importance of accompanying specialists, educators, health personnel and caring individuals.

The different types of obstacles and accompanying diseases of each child are other issues that are emphasized. Other information reported by family members has been observed as information to be taken into consideration when planning a holiday, such as eating and sleeping habits, special behaviors, favorite toys, drugs used, fears, allergies, underbelly, and being aggressive. It has been determined that it is important for parents to build a kitchen work Schedule to make sure that all the necessary food is provided during the holiday, and to make a meal plan by specifying meal times. The facilities to be visited include swimming pools, parks, natural beauty, entertainment center accessibility, roads suitable for wheelchair use, door and elevator widths, washbasins, toilets and other necessities. It would be useful to come together with families with all disabled children who will attend the vacation before planning a vacation, to discuss all the anticipated problems and concerns. Each participant is required to submit a copy of all information, identity documents, vaccination certificate, clothing list, allowance, physician report on inconvenience to travel, physician report on disabled and accompanying disease, family permission document, family doctor for emergency cases and parents' is recommended.

As a result; for a planned holiday, for good time. If the means of transport (bus, train, tram, airplane, etc.) are to be selected, and if public transport is preferred, the connections on the route should be planned. Taking out a list of worth seeing places will benefit from good time. It is recommended to take security precautions against danger that may occur from the beginning to the end of the holiday. Having a doctor and a nurse to accompany and having an experienced professional background is beneficial. During the holidays, it will be useful to allow plenty of movement in open air, to use bicycles for it, and to walk freely in the mountains and on the water, making it possible for children with mental disabilities to move freely. In addition to these, it is suggested that organizations such as handicrafts for developing hand skills, giving opportunities to talk freely in front of the society, theater, drama and theoretical lesson applications are suggested. Providing self-discovery, self-care (self-care skills), gaining everyday experiences and sporting activities should be seen as important in organizing everyday life to independent living. It is suggested that such holiday organizations should be held at least once a year for 10 days in terms of self-reliance, independent action, reduction of spiritual burden imposed on families and increas awareness of disabled people in society.

\section{REFERENCES}

Akandere M (2006). Educational school games, Nobel yayın, Ankara.

Camliyar H ve Camliyar H (1987). Child motion training and play, Can Ofset, Manisa.

Demirci A (2006). Physical education practices in primary education, Değişim Yayınları, 2006 İstanbul.

Demirci A (2013). Teaching technologies and material design in physical education and sports education, Nobel yayin, Ankara.

Demirci A, Demirci E, Demirci N (2013). Physical education and sports education with games, Nobel yayın, Ankara.

Demirci N (2004). İmportance of gaming education in the context of primary level primary school teachers' views. Kafkas Universitesi, Sosyal Bilimler Enstitusu, Yayınlanmamış Yuksek Lisans Tezi, Kars.

Ery1lmaz B (2010). Assessment of Disabled Market in Tourism and Bodrum Incorporation, Sakarya Universitesi Sosyal Bilimler Enstitusu, Yuksek Lisans Tezi, Sakarya.

EU (2004). Improving Information on AccessibleTourismforDisabled People, http://ec.europa.eu/enterprise/sectors/tourism /files/studies/improving_informationonacces sibility/ improving_accessibility_en.pdf.

EU (2013). AccessibleTourism, http://ec.europa.eu/enterprise/ sectors/tourism/ accessibility/index_en.htm. Gallahue D L, Ozmun J C, Goodway J D (2014). Understandig Motor Development. Infants, Children, Adolescents, Adults. Ceviri Dilara Sevimay Ozer-Abdurrahman Aktop, Nobel Akademi, Ankara. 
Gur A (2001). The roles of sportive activities in the process of adaptation of social disability to social life. T. C. Başbakanlık Özürlüler İdaresi Başkanlığı, Ankara.

Hazar M (1997). Physical education and training with sporda play, Tutibay yayınları, Ankara.

Karatepe H (1998). Revitalization and Rehabilitation of Injury in Community Education for Children with Disabilities (Ceviri), Karatepe Yayınları Ankara.

Kephart C. N, Godfrey B. B (1973). Movement Patternsand Motor Education. PrenticeHall, Inc. New Jersey.

Koca C (2017). New approaches in Physical Education and Sports Teaching symposium 6, 21-22 Ocak, Hacettepe Universitesi. Mersin Metropolitan Municipality Disabilities Department Presidency Mersin Disability Opportunities (Interview) 22.11.2016 Mersin.

Metin A (2013). The Importance of Accessibility in Barrier-free Tourism and Accessibility Criteria,http://worldhealthand3rdagetourism. org/PDFs/Ayhan_METIN.pdf

Resmi Gazete (1982). The Constitution of the Republic of Turkey, http:// www.tbmm.gov.tr/anayasa.htm Erişim Tarihi: 24.09.2017.

Okur N (2001). Investigation of Organization for the Disabled, T. C. Başbakanlık Ozurluler İdaresi Başkanlığı, Ankara.

Özer DS, Ozer M, K (2009). Motor development in children, Nobel yayın, Ankara.

Özer DS (2010). Physical education and sports for the disabled, Nobel yayın, Ankara.

Özturk F (1998). Sports with social dimensions, Bağırgan Yayınevi, Ankara.

Şahin F (2001). Place and importance of games in elementary science teaching, MU, Fen Bilimleri Eğitimi Sempozyumu, İstanbul TR62-09-02/041 Nolu Zihinsel Engelliler Spor Eğitim Merkezi Proje Kapsamında Mersin Universitesi Engelli cocuklarda tatil planlaması yapılırken nelere dikkat edilmelidir? Başlıklı 2009 yılı mersin universitesi bunyesinde ailelerle goruşmeler

Tutuncu O. Aydın I (2013). Accessible Tourism T. C. Dokuz Eylul University Sports Science and Technology Higher Education Recreation Area Anatolia: Tourism Researches Journal, Cilt 24, Say1 2, Guz: 261-263, İzmir
Yau M. K. McKercher B. Packer T. L (2004). Travelingwith a Disability: MoreThan an Access Issue, Annals of TourismResearch, 31 (4): 946-960.

Yorukoğlu A (1981). Development principles and child psychological development. Mental health and illnesses. Ozturk O (Ed.) Turkiye Sinir Ve Ruh Sağlığı Derneği Yayınları, Ankara. 